\title{
KONDISI EKOSISTEM TERUMBU KARANG DI LOKASI DAN BUKAN LOKASI PENYELAMAN PULAU MARATUA
}

\section{CONDITION OF CORAL REEFS IN DIVE SITES AND NON DIVE SITES IN MARATUA ISLAND, EAST KALIMANTAN}

\author{
Idris $^{1}$, Mikael Prastowo SW ${ }^{1} \&$ Basuki Rahmat ${ }^{2}$
}

\author{
'Yayasan TERANG \\ ${ }^{2}$ Yayasan KEHATI \\ Jl. Asyibaniah No 106. Kelurahan Pondok Jaya. Cipayung- Depok \\ Telp/Faks : 02129504088 \\ e-mail : idris@terangi.or.id
}

Diterima tanggal: 2 Mei 2018 ; diterima setelah perbaikan: 5 April 2019 ; Disetujui tanggal: 25 April 2019 DOI: http://dx.doi.org/10.15578/jkn.v14i1.6898

\begin{abstract}
ABSTRAK
Terumbu karang Indonesia memiliki ancaman kerusakan tertinggi di dunia. Upaya-upaya konservasi membutuhan data dan informasi ilmiah yang akurat. Kegiatan non ekstraktif seperti wisata bahari memberikan pengaruh terhadap kondisi terumbu karang, wisatawan yang menikmati keindahan alam bawah laut melalui diving ataupun snorkeling dapat mempengaruhi perubahan kondisi ekosistem terumbu karang. Oleh sebab itu, tersedianya data spasial proses-proses lingkungan dan gangguan antropogenik perlu dipahami dengan baik. Pengamatan menggunakan protokol pemantauan terumbu karang untuk menilai kawasan konservasi perairan, yang dilakukan dari 15 Maret hingga 19 Maret 2016. Pengamatan ini dilakukan pada terumbu di sebelah barat selatan dari Pulau Maratua disesuaikan dengan kondisi perairan. Terdapat 9 (sembilan) lokasi pengamatan yang mewakili lokasi penyelaman wisata dan lokasi yang tidak digunakan untuk penyelaman wisata. Tujuan dari pengamatan ini adalah untuk mengetahui pengaruh kegiatan wisata terhadap kondisi terumbu karang di Pulau Maratua, berdasarkan persentase penutupan karang hidup, kelimpahan ikan karang dan avertebrata bentik yang menjadi asosiasi terumbu karang. Hasil pengamatan persen penutupan karang hidup dilokasi penyelaman ratarata mencapai nilai $48 \%$ (sedang) dan pada lokasi bukan penyelaman mencapai nilai 43\% (sedang). Jenis ikan karang yang paling banyak ditemukan di lokasi pengamatan adalah jenis Pterocaesio diagramma, Caesio cuning dan Cirrhilabrus cyanopleura sedangkan Didemnum molle merupakan Tunicata yang sangat mendominasi di lokasi. Berdasarkan hasil analisis sidik ragam menunjukkan bahwa lokasi penyelaman dengan bukan lokasi penyelaman tidak berbeda nyata (analisis ANOVA single factor, $\mathrm{F}_{\text {tabel }}=1,36 ; \mathrm{F}_{\text {hitung }}=4,28 ; \mathrm{P}<0,05$ ). Artinya bahwa kegiatan wisata bahari yang sedang terjadi di Pulau Maratua tidak berpengaruh terhadap kondisi terumbu karang.
\end{abstract}

Kata kunci: Ekosistem terumbu karang, penyelaman, Pulau Maratua, konservasi, antropogenik.

\begin{abstract}
Maratua Island lies in the Makassar Strait was a destination for marine tourism especially international divers. Currently, no activities in monitoring the effect of tourism is in place, and therefore, there is a need compare the condition of the dive sites and non-dive site as a proxy for the impact of diving to coral reefs. Nine locations in total representing dive and non-dive sites were observed. The purpose of this research is to find out the effect of tourism activities on the condition of coral reefs on Maratua Island, based on the percentage of live coral cover, abundance of reef fisehes and benthic invertebrates. The result shows that the condition of dive sites and non-dive sites were generally the same, 48\% (Good) and 43\% (Good) respectively. Analysis using ANOVA single factor also shows that there is no significant difference between dive sites and non-dive sites $\left(F_{\text {crit }}=1.36 ; F_{\text {calc }}=\right.$ 4.28, $P<0.05)$. This means that diving not yet posed a significant threat to the coral reefs in Maratua Island. Other animal were also being observed and the most abundant fish are Pterocaesio diagramma, Caesio cuning, and Cirrhilabrus cyanopleura.
\end{abstract}

Keywords: Coral reefs, dive sites, Maratua Island, tourism impact.

$\overline{\text { Kondisi Ekosistem Terumbu Karang di Lokasi dan Bukan Lokasi Penyelaman Pulau Maratua - Idris, Mikael Prastowo \& }}$ 


\section{PENDAHULUAN}

Terumbu karang Indonesia merupakan ekosistem dengan keanekaragaman hayati tertinggi di dunia, terdapat lebih dari 2000 spesies ikan, 650 jenis karang;. Indonesia dinyatakan sebagai pusat keanekaragaman hayati laut dunia (Allen \& Werner, 2002; Allen \& Adrim, 2003; Allen, 2008). Indonesia juga menjadi tempat bagi pertumbuhan terumbu karang yang unik, misalnya pada Pulau Maratua, Kalimantan Timur. Pulau Maratua merupakan salah satu pulau pada Kepulauan Derawan. Menurut Tomascik et al. (1997) Pulau Maratua memiliki kawasan dengan luas daratan sebesar $384,3 \mathrm{~km}^{2}$, dan memiliki terumbu karang tepi, laguna, atol, dan danau air laut. Secara geografis Pulau Maratua terletak di $02^{\circ} 15^{\prime} 12^{\prime \prime}$ LU dan $118^{\circ} 38^{\prime} 41^{\prime \prime}$ BT. Kondisi iklim kawasan tersebut mengalami musim kemarau pada bulan Juli hingga September dan musim penghujan pada Oktober hingga Mei. Musim dipengaruhi oleh faktor oseanografis, terutama oleh Arus Lintas Indonesia (Arlindo), yang mengalir dari Samudra Pasifik menuju Samudra Hindia melewati Selat Makassar (Wyrtki, 1961). Pergerakan lempeng tektonik juga menyebabkan pengangkatan kawasan terumbu karang dan menyebabkan terbentuknya beragam variasi habitat terumbu karang, mangrove, dan padang lamun. Kondisi tersebut menyebabkan tersedianya lingkungan yang mendukung keanekaragaman hayati laut yang tinggi (Cornell \& Karlson, 2000).

Kawasan pulau-pulau kecil memiliki potensi sumberdaya alam dan jasa lingkungan yang tinggi. Salah satu jasa lingkungan yang dimiliki adalah keindahan terumbu karang. Jasa ekosistem yang ada diterumbu karang salah satunya adalah dalam bentuk kegiatan wisata bahari. Kegiatan wisata bahari yang berkelanjutan sangat penting untuk diterapkan di ekosistem terumbu karang, untuk itu konsep wisata bahari yang cocok adalah konsep ekowisata (Purwita, 2010). Menurut Yulianda (2007) mendefinisikan ekowisata bahari sebagai sebuah konsep pemanfaatan sumberdaya alam pesisir secara berkelanjutan dengan mengutamakan layanan jasa sebagai objek wisata. Kawasan pulau-pulau kecil yang memiliki terumbu karang sangat rentan terhadap tekanan, eksploitasi secara berlebihan akan menyebabkan kerugian dalam jangka panjang, terutama berkaitan dengan keindahannya yang unik dilihat dari keragaman dan kelimpahan biota penyusunnya.

Sebagai salah satu pulau kecil, Pulau Maratua memiliki potensi kekayaan terumbu karang yang menjadi favorit bagi penyelam dan memiliki 40 titik spot menyelam yang layak diperhitungkan (kliksangatta.com). Selain terkenal dengan keindahan bawah lautnya, Pulau Maratua juga terkenal akan keindahan danau yang sangat unik yaitu danau Kakaban. Terdapat ubur-ubur yang tidak menyengat dan jinak untuk didekati para wisatawan yang berenang disana. Selain terdapat di Danau Kakaban, ubur-ubur jenis ini juga terdapat di Danau Haji Buang yang terletak diantara Kampung Bohe Bukut dan Kampung Payung-Payung. Sumberdaya manusia di Pulau Maratua yang berkecimpung dalam dunia penyelaman dan pemanduan sudah cukup memadai, sampai saat ini telah ada kelompok guide yang mempunyai kemampuan dasar memandu tamu sebanyak 20 orang dan sudah menerapkan konsep ekowisata ramah lingkungan sejak tahun 2008, sehingga diharapkan kegiatan wisata disana berjalan dengan konsep ramah lingkungan. Data dari dinas kebudayaan dan Pariwisata Berau menyatakan bahwa wisatawan yang berkunjung ke Pulau Maratua mencapai 3000 orang di tahun 2017 yang tersebar di 40 spot diving (Disbudpar Berau, 2017).

Terumbu karang di Indonesia termasuk yang memiliki ancaman tertinggi di dunia. Upaya-upaya konservasi membutuhan data dan informasi ilmiah yang akurat dan handal terkait dengan kondisi taksa dan lingkungan (Mora et al., 2003; Burke et al., 2002). Tidak berbeda dengan Kepulauan Derawan. Walaupun kawasan pesisir dan laut pada beberapa kawasan masih dianggap alami, terdapat ancaman konversi lahan pantai menjadi tambak, serta meningkatnya kerusakan terumbu karang akibat perikanan merusak dan ilegal (Estradivari \& Yusri, 2006). Selain itu kegiatan non ekstraktif seperti wisata bahari memberikan pengaruh terhadap kondisi terumbu karang, wisatawan yang menikmati keindahan alam bawah laut melalui diving ataupun snorkeling dapat mempengaruhi perubahan kondisi ekosistem terumbu karang (Loya, 1976 dalam Liew, 2001). Bahkan beberapa penelitian menyebutkan bahwa hampir semua wisatawan melakukan kontak fisik dengan terumbu karang selama wisata selam dan snorkeling. Sebagian besar kontak fisik tersebut tidak menimbulkan kerusakan terhadap terumbu karang, namun terdapat beberapa wisatawan yang menyebabkan dampak kerusakan signifikan akibat menginjak dan mengambil karang (Hawkins, 1992; Harriot et al., 1997). Kegiatan memanfaatkan jasa ekosistem terumbu karang untuk kegiatan wisata bahari perlu memperhitungkan daya dukung lingkungan supaya tidak menyebabkan penurunan fungsi terumbu karang, oleh sebab itu perlu adanya kajian terkait pengaruh 
kegiatan wisata bahari terhadap ekosistem terumbu karang di Pulau Maratua, sehingga mengarah ke wisata yang ramah lingkungan.

Adapun tujuan dari kajian ini adalah untuk mengetahui keanekaragaman biota laut di sebelah barat-selatan Pulau Maratua, untuk mengetahui kondisi tutupan karang keras di sebelah barat-selatan Pulau Maratua dan untuk mengetahui pengaruh kegiatan wisata penyelaman terhadap kondisi terumbu karang di sebelah barat-selatan Pulau Maratua.

\section{BAHAN DAN METODE}

Pengamatan ini dilakukan pada terumbu di sebelah barat - selatan dari Pulau Maratua disesuaikan dengan kondisi perairan. Terdapat 9 (sembilan) lokasi pengamatan yang mewakili lokasi penyelaman wisata dan lokasi yang tidak digunakan untuk penyelaman wisata. Pengamatan dilakukan dari tanggal 15 Maret hingga 19 Maret 2016. Lokasi penelitian dapat dilihat pada Gambar 1.

\section{Pengambilan data}

Metode yang digunakan untuk menilai komunitas ikan karang dan bentik berdasarkan panduan "Protokol Pemantauan terumbu karang untuk menilai kawasan konservasi perairan" (Ahmadia et al., 2013). Tiga transek sepanjang $50 \mathrm{~m}$ (total panjang $150 \mathrm{~m}$ ) dibentangkan sejajar garis pantai dan mengikuti kontur dasar perairan. Pengamatan dilakukan di lereng terumbu dengan kedalaman berkisar antara 5 - 10 meter.

\section{Pengamatan kondisi tutupan karang hidup}

Metode pengamatan tutupan karang menggunakan transek poin dan transek foto bawah air. Pengamat akan mencatat informasi bentuk hidup karang (life form) pada setiap titik $50 \mathrm{~cm}$ dan seterusnya sampai meter

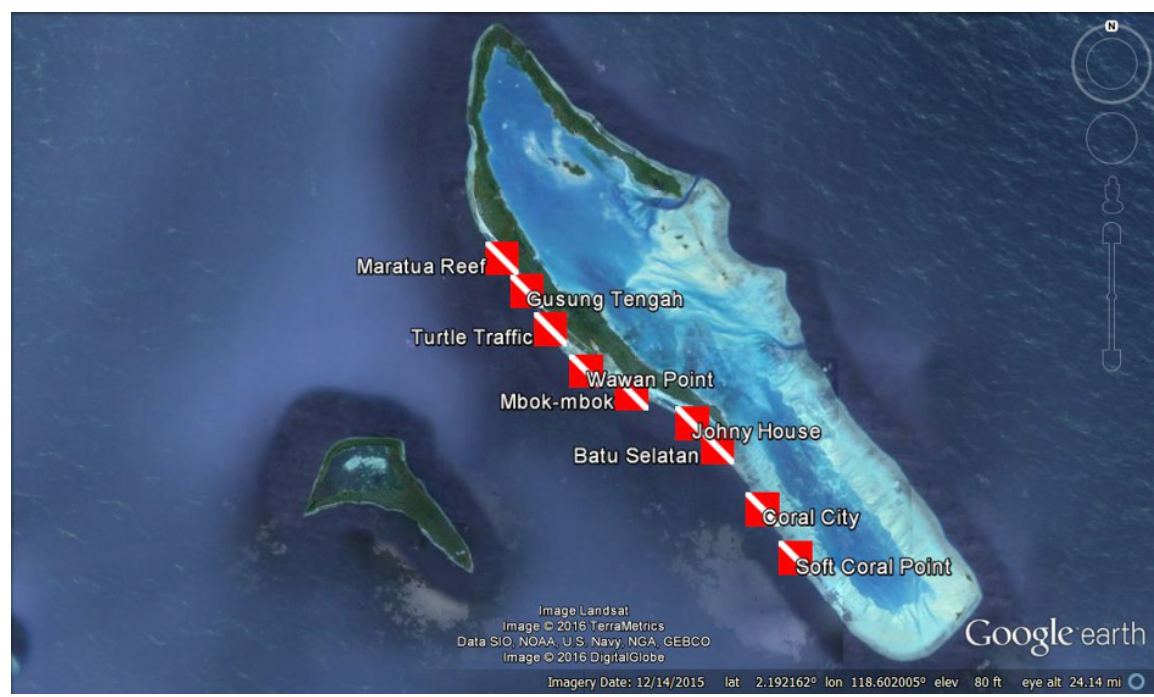

Gambar 1. Peta Lokasi Pengamatan. Sumber : google earth.

Figure 1. Map of Observation Location. source: google earth

Tabel 1. Daftar lokasi pengamatan

Table 1. List of observation stations

\begin{tabular}{lllll}
\hline No & Lokasi & Lintang $\left({ }^{\circ}\right)$ & Bujur $\left({ }^{\circ}\right)$ & Keterangan \\
\hline 1 & Maratua reef & 2,2255 & 118,5727 & Dive Site \\
2 & Coral garden/Mbok-mbok 2,1773 & 118,6188 & Dive Site \\
3 & Turtle Traffic & 2,2000 & 118,5902 & Dive Site \\
4 & Batu Selatan & 2,1584 & 118,6488 & Dive Site \\
5 & Soft Coral Point & 2,1203 & 118,6753 & Non Dive Site \\
6 & Coral City & 2,1372 & 118,6641 & Non Dive Site \\
7 & Gusung Tengah & 2,2137 & 118,5815 & Non Dive Site \\
8 & Wawan Point & 2,1850 & 118,6028 & Non Dive Site \\
9 & Johny House & 2,1669 & 118,6400 & Dive Site \\
\hline
\end{tabular}

$\overline{\text { Kondisi Ekosistem Terumbu Karang di Lokasi dan Bukan Lokasi Penyelaman Pulau Maratua - Idris, Mikael Prastowo \& }}$ 
terakhir (Hill \& Wilkinson, 2004). Proses identifkasi dibantu dengan menggunakan buku panduan yaitu Lieske \& Myers (1994); Veron (2000); Gosliner \& Williams (1996); English et al. (1997); de Voogd (2005); dan Sprung (2001).

\section{Kelimpahan ikan karang}

Pengamatan dilakukan pada siang hari, sehingga target pengamatan hanya terbatas pada hewan-hewan diurnal - hewan yang mencari makan pada siang hari. Pengamatan ikan karang menggunakan metode sensus visual bawah air (underwater visual cencus $=\mathrm{UVC}$ ) dan transek sabuk (belt transect) lebar transek 5 meter, sehingga luas daerah pengamatan menjadi $250 \mathrm{~m}^{2}$ setiap transeknya. Informasi yang dicatat berupa jenis dan jumlah ikan karang yang ditemukan, sampai level jenis. Proses identifkasi dibantu dengan menggunakan buku panduan yaitu Allen \& Steene (1998); Kuiter \& Tonozuka (2003); Kuiter \& Debelius (1997); dan Randall dkk. (1997).

\section{Kelimpahan avertebrata bentik}

Pengamatan avertebrata bentik menggunakan metode transek sabuk (belt transect) dengan lebar transek 2 meter, sehingga luas daerah pengamatan menjadi $100 \mathrm{~m}^{2}$ pada setiap transeknya. Informasi yang dicatat berupa jenis dan jumlah avertebrata bentik yang ditemukan, sampai level jenis. Proses identifkasi dibantu dengan menggunakan buku panduan yaitu Bianchi et al. (2004); Carpenter \& Niem (1998), Clark
\& Rowe (1971); Collin \& Arnesson (1995); Debelius (1996); dan Dharma (1992).

\section{Analisa Data}

Data yang dihasilkan akan dianalisa dengan menggunakan persamaan-persamaan berikut ini :

a. Perhitungan persentase kategori tutupan substrat menggunakan persamaan :

$\mathrm{Li}=(\mathrm{ni} / \mathrm{L}) \times 100 \%$

di mana,

$\mathrm{Li}=$ Persentase tutupan biota karang ke- $\mathrm{i}$

$\mathrm{ni}=$ panjang total kelompok biota ke-i; dan

$\mathrm{L}=$ panjang total transek garis.

Keanekaragaman diketahui dengan menggunakan indeks Shannon-Wiener, yang memperhitungkan kekayaan jenis dan kemerataan (Magurran, 1988; Ludwig \& Reynolds, 1998).

b. Keanekaragaman dihitung dengan persamaan :

$\mathrm{H} \neg \mathrm{i}^{\prime}=\sum \mathrm{P} \neg \mathrm{i} \operatorname{Ln} \mathrm{Pi}$

di mana,

$\mathrm{Pi}=$ proporsi kelimpahan jenis $\mathrm{i}$

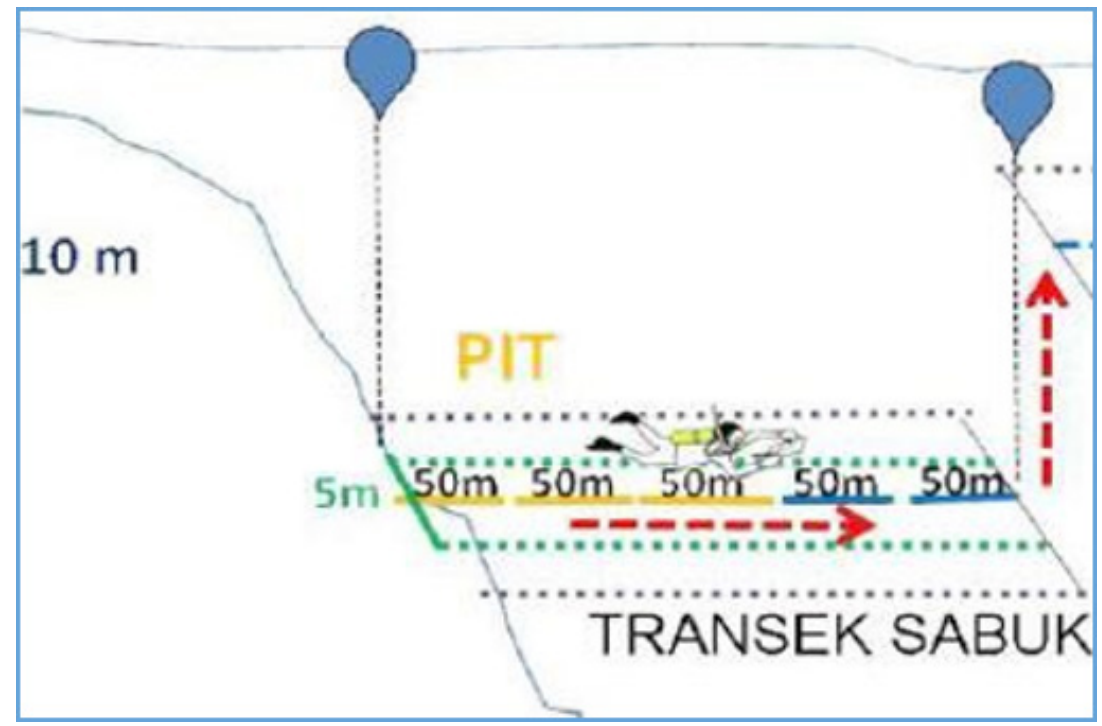

Gambar 2. Pengamatan Kesehatan Terumbu Karang menggunakan Metode Reef Health (Wilson \& Green, 2009).

Figure 2. Coral Reef Health Observation using Reef Health assessmentMethod (Wilson \& Green, 2009). 
c. Kemerataan dihitung dengan persamaan :

$\mathrm{Ei}{ }^{\prime}=\mathrm{Hi}^{\prime} / \mathrm{H}^{\prime} \max$

di mana,

$\mathrm{H}^{\prime} \quad$ = indeks keanekaragaman

$\mathrm{H}^{\prime} \max =\mathrm{H}^{\prime} / \mathrm{Ln} \mathrm{S}$

$\mathrm{S} \quad=$ kekayaan jenis.

d. Dominansi dihitung dengan persamaan :

$\mathrm{D}=\sum \mathrm{Pi} 2$

di mana,

$\mathrm{Pi}=$ proporsi kelimpahan jenis $\mathrm{i}$.

e. Perbedaan persentase penutupan karang keras dianalisis menggunakan analisis sidik ragam (Analysis of Variance) dengan satu faktor (Neter dkk, 1996; Zar, 1996).

Penentuan kategori penutupan karang dilihat dari besarnya persentase penutupan karang keras dan disesuaikan berdasarkan kategori Gomez \& Yap (1988) dapat dilihat dalam Tabel 2.

\section{HASIL DAN PEMBAHASAN}

Pulau Maratua memiliki keanekaragaman ikan yang cukup tinggi. Hasil pengamatan berhasil menemukan sebanyak 144 spesies ikan karang dari suku Caesionidae, Pomacentridae, Serranidae, Labridae, Chaetodontidae, Acanthuridae, Scaridae, Zanclidae, Siganidae, dan berbagai suku lainnya. Suku ikan dengan kekayaan jenis tertinggi adalah Pomacentridae dan Labridae dengan 38 spesies dan 28 spesies. Hal yang unik adalah suku Caesionidae memiliki jumlah spesies 3 tetapi memiliki kelimpahan tertinggi, yaitu 19.108 individu/ha. Ikan tersebut merupakan ikan komersial yang bersifat planktivora. Tingginya suku ekor kuning juga ditemukan di banyak lokasi di Indonesia, misalnya seperti di Kepulauan Seribu (Maduppa et al., 2013; Estradivari \& Yusri, 2006). Hal

Tabel 2. Kategori persentase penutupan karang keras Table 2. The percentage category of hard coral cover

\begin{tabular}{ll}
\hline $\begin{array}{l}\text { Persentase Pentupan } \\
\text { karang Keras (\%) }\end{array}$ & Kategori/Kriteria \\
\hline $0-24,9$ & Buruk \\
$25-49,9$ & Sedang \\
$50-74,9$ & Baik \\
$75-100$ & Sangat Baik \\
\hline
\end{tabular}

menarik berikutnya adalah Suku Serranidae ternyata juga menjadi salah satu suku yang jumlahnya melimpah. Caesionidae dan Serranidae biasanya merupakan ikan target konsumsi, akan tetapi jumlahnya masih tinggi. Hal tersebut menunjukkan bahwa tekanan perikanan untuk kedua suku tersebut masih dapat ditoleransi. Kedua suku ikan tersebut juga biasanya menarik minat para penyelam sehingga dapat dijadikan sebagai daya tarik wisata. Selain itu, pada lokasi Soft Coral Point, dapat ditemukan spotted garden eel (Heteroconger hassi). yang dapat menjadi daya tarik khusus untuk penyelam. Jika dilihat dari tingkat trofi, Pulau Maratua didominasi oleh ikan planktivora dan omnivora, sebaliknya ikan herbivor kelimpahannya paling sedikit dibandingkan dengan kelompok trofi yang lain. Hal ini perlu menjadi perhatian karena jumlah ikan herbivor yang lebih sedikit akan menyebabkan pertumbuhan alga di terumbu karang tidak terkendali. Ikan-ikan herbivor di terumbu karang berperan sebagai pengendali utama populasi alga (Obura \& Grimsdith, 2009). Dominici dkk. (2006) menemukan bahwa kelimpahan jenis ikan planktivor memang sangat dominan dengan kelimpahan yang melebihi $50 \%$ dari seluruh kelimpahan ikan karang.

Survei berhasil menemukan sebanyak 133 spesies avertebrata bentik non karang, yang terdiri atas Annelida, Arthropoda, Cnidaria, Echinodermata, Mollusca, Porifera, dan Chordata subfilum Tunicata. Kawasan terumbu karang di Pulau Maratua dipenuhi oleh 133 spesies avertebrata bentik. Filum dengan jumlah spesies terbanyak adalah Porifera dengan 56 spesies, sedangkan jumlah spesies terendah adalah Annelida (2 spesies). Lokasi dengan jumlah spesies terendah yang ditemukan adalah pada Soft Coral Point (30 spesies), sedangkan lokasi dengan jumlah spesies tertinggi adalah Gusung Tengah (55 spesies). Biota yang sering ditemukan adalah Tunicata dan spons. Persentase tutupan karang mati, telah memberikan peluang kepada Tunicata untuk menempel, tumbuh dan menutupi permukaan/dasaran. Selama pengamatan Tunicata banyak ditemukan melingkupi patahan karang dan karang mati. Spons di Maratua sangat beragam, total berhasil ditemukan 56 spesies Porifera. Hal serupa juga ditemukan oleh Becking et al. (2013) yang menemukan 30 spesies spons di Hutan Mangrove di pesisir Pulau Maratua dan 18 spesies spons di Danau Haji Buang.

Hal yang perlu diperhatikan adalah, baik Tunicata maupun Porifera merupakan hewan invasif yang berkompetisi dengan karang. Keduanya juga diketahui dapat menyerang karang. Dengan cepat 
mereka akan menutupi permukaan karang yang mati, sehingga memperkecil kemungkinan larva karang untuk menempel, tumbuh dan berkembang. Tunicata (Subfilum Urochordata) selain berkompetisi ruang dengan larva karang, mereka juga mampu menginvasi karang yang masih hidup (Stoecker, 1978; Collin \& Arnesson, 1995; Suwanborirux, 2002). Pertahanan karang berupa tentakel penyengat dapat dilewati oleh spons sehingga karang akan ditutupi oleh spons (Wahab et al., 2014; Gonzalez-Rivero et al., 2011). Hal yang menarik lainnya adalah ditemukannya keong triton (Charonia tritonis) di Maratua Reef dan lola (Trochus niloticus) di Turtle Traffic. Kedua hewan tersebut merupakan hewan dilindungi yang sudah sulit ditemukan dan kedua hewan ini bisa menjadi target foto bagi para wisatawan yang berkunjung.

Ekosistem terumbu karang merupakan objek utama wisata selam dan snorkeling. Menurut Loya (1976) dalam Liew (2001) meningkatnya kegiatan wisata bahari dapat mempengaruhi kondisi terumbu karang. Dampak yang diakibatkan oleh masing-masing perilaku wisatawan terhadap terumbu karang sangat kecil, namun secara kumulatif perilaku tersebut dapat memberikan tekanan terhadap terumbu karang dan mempengaruhi persentase tutupan karang (Hawkins et al., 1992; Barker et al., 2003). Aktivitas wisata bahari dapat memberikan dampak kerusakan secara langsung maupun tidak langsung (Dahuri et al., 2003). Dampak langsung terjadi karena adanya kontak fisik dengan terumbu karangan baik disengaja maupun tidak sengaja oleh penyelam, perenang atau pun oleh jangkar kapal wisatawan. Sedangkan dampak tidak langsung terjadi karena pembangunan fasilitas wisata seperti hotel, dermaga dan fasilitas wisata lainnya yang secara tidak langsung mengubah fungsi dan pemanfaatan wilayah pesisir.

Berdasarkan hasil pengamatan didapatkan bahwa persen penutupan karang hidup dilokasi penyelaman rata-rata mencapai nilai $48 \%$ (sedang) dan pada lokasi bukan penyelaman mencapai nilai 43\% (sedang) menurut kriteria Gomez \& Yap (1988). Persentase tutupan karang hidup di lokasi penyelaman sedikit lebih baik dibandingkan dengan lokasi bukan penyelaman, karena diduga lokasi bukan penyelaman relatif lebih banyak kegiatan perikanan yang menggunakan caracara kurang ramah lingkungan seperti bubu yang terpasang diterumbu karang. Penutupan KM (21\%), KL $(13 \%)$ dan biotik (12\% dan 11\%) hampir tidak ada perbedaan. Perbedaan yang signifikan terlihat pada tutupan abiotik ( $6 \%$ dan $12 \%$ ). Dimana sebagian besar komponen abiotik didominasi oleh pasir dan sedikit pecahan karang. Komponen pecahan karang yang patah-patah dan terangkat banyak ditemukan di lokasi penyelaman yang diindikasikan akibat kegiatan wisata (penyelam maupun jangkar kapal). Hasil kajian Laksono \& Mussadun (2014) di Pulau Karimun Jawa menyatakan wisatawan yang melakukan wisata air sering menginjak karang. Rophael \& Inglis (1997) beberapa perilaku wisatawan yang berpotensi dapat merusak terumbu karang antara lain menendang karang, memegang karang, berjalan di atas karang, serta penambatan jangkar di karang. Hammerton \& Bucher (2015) bahwa gerakan fins yang tidak terkontrol sering mengakibatkan patah atau goresan pada karang keras, spons, ascidians, dan terangkatnya hewan invertebrata lainnya. Ada juga kontak yang disengaja, dimana seorang penyelam secara sadar menggunakan bagian tubuh mereka atau perlengkapannya untuk menstabilkan

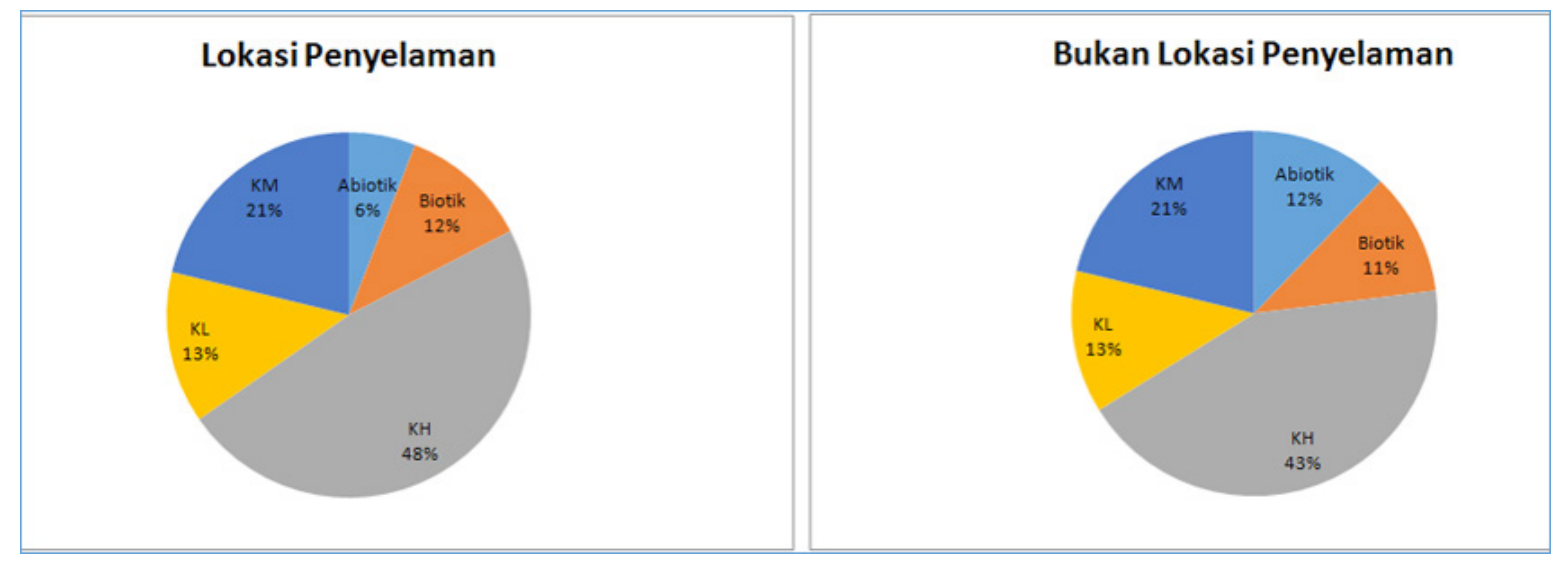

Gambar 3. Perbandingan Komposisi Rerata Penutupan Kategori Substrat Pada Lokasi Penyelaman dan Bukan Lokasi Penyelaman (KM=Karang Mati, KH=Karang Hidup, Abiotik=Benda mati, Biotik =benda hidup dan KL=karang Lunak). Figure 3. Comparison of Average Composition of Closing Substrate Categories at Dive Sites and Non Dive Sites (KM= Dead Coral, $K H=$ Living Coral, Abiotic $=$ Dead objects, Biotic $=$ living things and $K L=$ Soft corals). 
diri terhadap terumbu karang, termasuk para penyelam yang menyentuh substrat dengan tangan mereka, dan menstabilkan diri mereka di terumbu karang dengan tangan atau kaki. Jenis kontak ini sangat umum di kalangan fotografer bawah air. Kemungkinan lain adalah karang juga menghadapi tekanan alami seperti arus dan gelombang kuat saat musim-musim tertentu.

Hal yang perlu diperhatikan adalah patahan karang yang terlempar juga akan merusak karang di sekitarnya dan susah menjadi tempat penempelan juana karang. Menurut Razak (2006) daerah yang dipenuhi dengan patahan karang tersebut sering disebut sebagai rubble killing field, dimana karang tidak dapat tumbuh. Patahan karang akan selalu bergerak akibat pengaruh dinamika air, sehingga juwana karang yang menempel akan mati karena terbalik atau terkubur ketika menempel pada patahan karang. Namun karang mati (patahan-patahan dan karang yang terangkat) bisa menjadi substrat atau tempat hidup bagi juwana karang. Bachtiar (2001) menulis substrat pecahan karang, karang mati, dan batu kapur (rock) dapat berfungsi sebagai substrat penempelan juwana karang ketika dalam kondisi stabil. Sayangnya tingginya populasi hewan invasive seperti tunicata dan spons membuat juwana karang akan sulit berkompetisi. Tekanan terhadap terumbu karang perlu dikendalikan.

Berdasarkan komposisi bentuk pertumbuhan karang (life form) ditemukan pada kedua lokasi pengamatan bahwa kategori karang keras didominasi oleh bentuk pertumbuhan karang bercabang (CB) sebanyak 65\% dan $62 \%$ ), selanjutnya didominasi oleh karang masif sebanyak (14\% dan $16 \%)$ dan yang paling sedikit adalah bentuk pertumbuhan karang jamur (CMR) yaitu sebanyak (2\%). Persentase tutupan karang bercabang sedikit lebih tinggi didaerah penyelaman, karena sebagian besar wisatawan dan pemandu wisata yang menyelam telah menerapkan prinsip ekowisata, hal ini terlihat dari 20 orang pemandu wisata sudah pernah mendapatkan pelatihan sebagai pemandu ekowisata pada tahun 2008. Menurut Lim (1998) komposisi terumbu karang bercabang dan lembaran lebih disukai oleh penyelam dibandingkan karang masif, namun lebih rapuh dan mudah patah oleh kontak dengan penyelam, perenang ataupun kapal. Juhasz et al. (2010) menyatakan bahwa berbagai bentuk pertumbuhan karang merespon secara berbeda untuk gangguan fisik yang disebabkan oleh manusia dengan koloni besar memiliki toleransi yang lebih tinggi daripada bercabang koloni. Dengan demikian, kerentanan bentuk morfologis yang berbeda terhadap kerusakan akan menyebabkan pergeseran dominasi spesies. Berdasarkan komposisi bentuk pertumbuhan maka kedua lokasi merupakan lokasi yang menarik untuk penyelam maupun perenang karena lokasi didominasi oleh pertumbuhan karang bercabang.

Marga karang keras yang ditemukan dikedua lokasi pengamatan didominasi oleh marga Acropora, Montipora, Porites, Seriatopora dan Pocillopora. Total marga karang keras yang ditemukan adalah sekitar 32 marga. Dominannya marga Acropora sesuai dengan tingginya tutupan karang keras dengan kategori karang bercabang dan diperkuat juga dengan dominannya ikan karang dari suku Pomacentridae (Ikan betok). Sebagaimana pernyataan Suharti (1996) bahwa dominasi suku Pomacentridae ini berkaitan

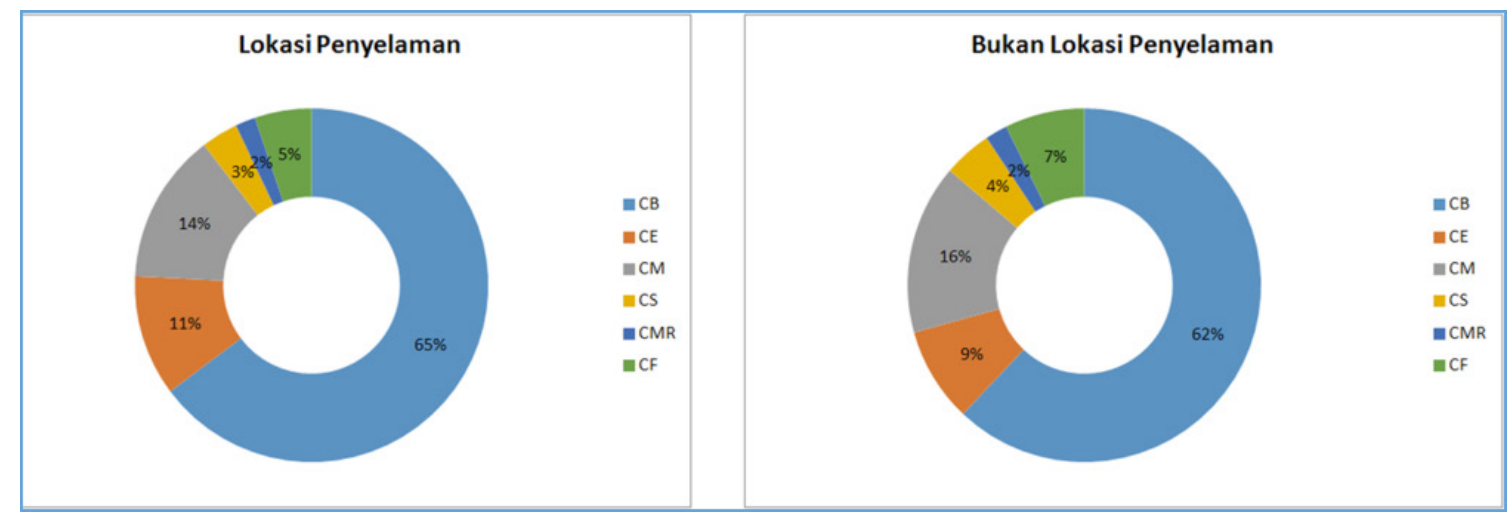

Gambar 4. Perbandingan komposisi rerata penutupan kategori substrat berdasarkan bentuk pertumbuhan karang keras pada lokasi penyelaman dan bukan lokasi penyelaman $(\mathrm{CB}=$ Karang bercabang, $\mathrm{CE}=$ Karang mengerak, $\mathrm{CM}=\mathrm{Karang} \mathrm{Massive}$, $\mathrm{CS}=$ Karang submassive, $\mathrm{CF}=$ Karang foliose dan CMR- Karang Jamur).

Figure 4. Comparison of the composition of the average cover of substrate categories based on the hard coral life formation growth at the dive site and not the dive site $(C B=$ Coral branching, $C E=$ Coral crust, $C M=M a s s i v e ~ C o r a l$, $C S=$ Submassive Coral, $C F=$ Foliose Coral and CMR-Coral Mushroom) 
erat dengan dominanya bentuk pertumbuhan karang acropora bercabang dan karang bercabang lainnya yang memiliki banyak relung-relung, karena sebagaimana diketahui bahwa jenis-jenis ikan Pomacentridae sering menghuni celah-celah pada cabang karang keras tersebut. Bahkan, Booth (2002) menemukan bahwa dari enam spesies Pomacentridae yang ia teliti, masing-masing memiliki preferensi sendiri terhadap marga karang keras. Pomacentridae cenderung rentan terhadap kerusakan habitat pada terumbu karang (Pratchett et al., 2012).

Berdasarkan kesesuaian untuk minat penyelam bahwa dominanya marga Acropora dan karang bercabang lebih menarik minat wisatawan dibandingkan dengan bentuk pertumbuhan karang lainnya. Lim (1998) menulis komposisi terumbu karang bercabang dan lembaran lebih disukai oleh penyelam dibandingkan karang masif, namun lebih rapuh dan mudah patah oleh kontak dengan penyelam, perenang ataupun kapal. Hal ini juga diperkuat dengan hasil pengamatan di lokasi penyelaman yang didapatkan bahwa kategori karang mati didominasi oleh pecahan karang (rubble). Zhang Li-Ye., S. Chung \& J.w. Qiu (2016) menyimpulkan bahwa aktivitas menyelam di Pulau Mabul telah menyebabkan berbagai jenis kerusakan yang berbeda pada bentuk karang. Pada daerah tepi terumbu, karang bercabang mengalami lebih banyak kerusakan dari daripada karang masif pada lereng terumbu yang lebih dalam.

Kondisi terumbu karang pada lokasi penyelaman dan bukan lokasi penyelaman terlihat tidak jauh berbeda (48\% dan 43\%) dan masuk dalam kategori sedang. Hal ini juga diperkuat dari hasil analisis sidik ragam menunjukkan bahwa lokasi penyelaman dan bukan lokasi penyelaman tidak berbeda nyata (analisis ANOVA singel factor, Ftabel $=1,36$; $F$ hitung $=4,28$, $\mathrm{P}<0,05)$. Artinya bahwa kegiatan wisata penyelaman yang sedang terjadi di Pulau Maratua tidak banyak berpengaruh terhadap kondisi terumbu karang disana. Namun yang perlu menjadi perhatian dalam pengembangan wisata bahari di Maratua adalah daya dukung (carrying capacity) yang sesuai dengan potensinya. Menurut Lim (1998) daya dukung suatu kawasan wisata adalah jumlah wisatawan yang dapat diakomodasi dengan tingkat kepuasan tertinggi dan berdampak minimal pada sumberdaya. Daya dukung merupakan konsep dimana ada pembatasan dalam pemanfaatan sumberdaya. Hal ini untuk menjaga kelestarian sumberdaya secara berkelanjutan tanpa menimbulkan kerusakan sumberdaya dan lingkungan. Menurut Clark (1996) bahwa daya dukung yang ada lebih sering diterapkan sebagai batas kegiatan wisata. Jika daya dukung lingkungan tidak diterapkan dalam pengembangan wisata maka akan mengarah pada penurunan kualitas lingkungan utamanya terumbu karang. Terlebih lagi jika terjadi pengayaan nutrien di perairan maka kondisi terumbu karang akan semakin tertekan (Burkepile et al., 2009). Indikasi ini terlihat dari kondisi kelimpahan Crinoidea yang tinggi menunjukkan indikasi pengayaan nutrisi dan dominannya spesies Porifera serta Tunicata, yang merupakan biota invasif, maka pemulihan ekosistem menjadi sulit. Berdasarkan pemodelan yang dibuat oleh González-Rivero et al. (2011), spons dapat menjadi dominan dan mengalahkan karang, apabila kompetisi dengan alga dan predasi oleh ikan rendah. Pengayaan nutrien dimungkinkan terjadi karena adanya kegiatan pembukaan lahan secara besar-besaran untuk bandara dan penginapan di P. Maratua. Daratan Pulau Maratua yang didominasi oleh pepohonan yang berfungsi menahan air hujan dan nutrien di daratan telah berubah menjadi tanah gersang. Penurunan nutrien dari daratan menuju perairan dapat terjadi akibat adanya alih fungsi lahan (Zul et al., 2013)
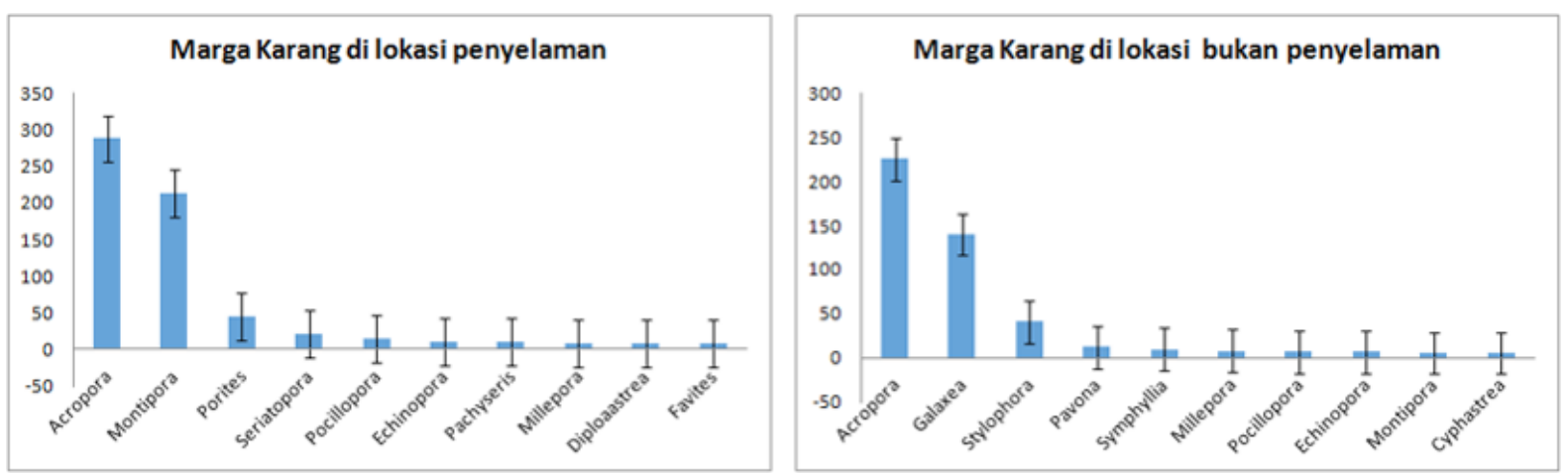

Gambar 5. Perbandingan 10 Marga Karang Keras Yang Ditemukan Di Lokasi. Figure 5. Comparison of 10 Hard Coral Clans which Found in Location. 


\section{KESIMPULAN DAN SARAN}

\section{Kesimpulan}

Berdasarkan hasil kajian ini dapat disimpulkan bahwa persen penutupan karang hidup di Pulau Maratua dilokasi penyelaman rata-rata mencapai nilai $48 \%$ (sedang) dan pada lokasi bukan penyelaman mencapai nilai $43 \%$ (sedang). Kondisi saat ini kegiatan wisata penyelaman di Pulau Maratua belum memberikan pengaruh yang signifikan terhadap kondisi tutupan karang. Selain itu hasil kajian ini juga telah menemukan sebanyak 144 spesies ikan karang yang didominasi oleh jenis ikan planktivora dan omnivora, sebanyak 133 spesies avertebrata bentik non karang dan sekitar 32 marga karang keras dari kelas Anthozoa. Namun juga perlu perhatian penuh pihak pengelola kawasan bahwa ditemukan juga kelimpahan Crinoidea yang tinggi menunjukkan indikasi adanya pengayaan nutrisi di perairan Pulau Maratua.

\section{Saran}

Pihak pengelola kawasan perlu melakukan kajian daya dukung lingkungan untuk kegiatan wisata bahari, sehingga kegiatan wisata yang akan dikembangkan tidak berdampak buruk pada ekosistem terumbu karang yang menjadi modal utama kegiatan wisata bahari di Pulau Maratua. Selain itu perlu pengembangan daerah penyelaman baru selain lokasi yang ada sekarang, untuk mengurangi dan melakukan monitoring secara berkala mengenai kondisi terumbu karang di Pulau Maratua yang mendukung pengelolaan wisata bahari.

\section{DAFTAR PUSTAKA}

Ahmadia, G. N., Wilson J. R., \& Green, A. L. (2013). Protokol Pemantauan Terumbu Karang Untuk Menilai Kawasan Konservasi Perairan. Terj. dari. Coral Reef Monitoring Protocol for Assessing Marine Protected Areas version 2.0. Coral Triangle Support Partnership, Jakarta: xiii +78 hlm.

Anonim. (2017). Pulau maratua berbenah segera lengkapi fasilitas penunjang. http://www.kliksangatta.com/ berita-8596-pulau-maratua-berbenahsegeralengkapi-fasilitas-penunjang. html diakses tanggal 0060917 jam 11.14

Allen, G. R., \& Steene, R. (1998). Indo-Pacific coral reef field guide. Sea Challengers, Danville: $378 \mathrm{hlm}$.

Allen, G. R., \& Werner, T. B. (2002). Coral reef fish assessment in the "Coral Triangle" of Southeastern Asia. Environmental Biology of Fishes, 65(2), 209214.

Allen, G. R., \& Adrim, M. (2003). Coral reef fishes of Indonesia. Zool. Stud, 42(1), 1-72.

Allen, G. R. ( 2008). Conservation hotspots of biodiversity and endemism for Indo-Pacific coral reef fishes. Aquatic Conservation: Marine and Freshwater Ecosystems, 18, 541-556.

Bachtiar, I. (2001). Reproduction of three scleractinian corals (Acropora cytherea, A. nobilis and Hydnophora rigida) in eastern Lombok Strait, Indonesia. Indones J Mar Sci 21,18-27.

Bachtiar, I.(2003). Reproduction of scleractinian corals: a review. Pusat Penelitian Pesisir dan Laut (P3L), Universitas Mataram. Biota 8(3):131-134.

Barker, N. H. L, Callum M. Roberts. (2003). Scuba Diver Behavior and Management of Diving Impact on Coral Reefs. Elselvier, 120(4):481-489.

Becking, L. E., Cleary, D. F. R., \& de Voogd, N. J. (2013). Sponge species composition, abundance, and cover in marine lakes and coastal mangroves in Berau, Indonesia. Mar. Ecol. Prog. Ser. 481, 105-120.

Burke, L., Selig, E., \& Spalding, M. (2002). Reefs at risk in Southeast Asia. World Resources Institute, United Nations Environment Program-World Conservation Monitoring Center, World Fish Center, dan International Coral Reef Action Network, USA: 40 hlm.

Burkepile, D. E., \& Hay. M. E. (2009). Nutrient versus herbivor control of macroalgal community development and coral growth on a Caribbean reef. Mar Ecol Prog Ser. 389, 71-84.

Clark, A. M., \& Rowe, F. W. E. (1971). Monograph of shallow-water Indo-West Pacific echinoderms. British Museum (Natural History), London: ix + 269 hlm.

Clark, J. R. (1996). Coastal zone management. Handbook. CRS Press. Lewis Publishers. Florida

Collin, P. L. \& Arnesson, C. (1995). Tropical Pacific Invertebrates. Coral Reef Press, California: $290 \mathrm{hlm}$.

Cornell, H. V., \& Karlson, R. H. (2000). Coral species richness: ecological versus biogeographical influences. Coral reefs, 19(1), 37 - 49.

Dahuri, R. (2003). Keanekaragaman Hayati Laut Aset Pembangunan Berkelanjutan Indonesia. PT. Gramedia Pustaka Utama. Jakarta.

De Voogd, N. J., \& van Soest, R. W. M. (2005). Indonesian sponges of the genus Petrosia Vosmaer (Demospongiae: Haplossclerida). Dalam: de Voogd, N.J. (2005). Indonesian Sponges. Biodiversity and mariculture potential. Phd thesis, University of Amsterdam, Amsterdam: 21-37 hlm.

Debelius, H. (1996). Nudibranchs and sea snails IndoPacific field guide. IKAN - Unterwasserarchiv, Frankfurt: $321 \mathrm{hlm}$.

Dharma, B. (1992). Siput dan Kerang Indonesia II. Verlag Christa Hemmen, Wiesbaden: 135 hlm.

Dinas Kebudayaan dan Pariwisata Kabupaten Berau. (2017). Penguatan Ekonomi Masyarakat Kabupaten Berau Bidang Industri Pariwisata Tahun 2018. Rapat Koordinasi Perencanaan Se Kalimantan Timur Tahun 2017 Selasa 7 Maret 2017, Novotel Balikpapan.

Dominici, A. A., \& Wolf, M. (2006). Reef fish community 
structure in the Tropical Eastern Pacific (Panama): living on a relatively stable rocky reef environment. Helgol Mar Res, 60(4), 287-305.

English, S., Wilkinson, C., \& Baker, V. (1997). Survey Manual for Tropical Marine Resources (2nd edition). Australian Institute for Marine Science, Townsville

Estradivari \& Yusri, S. (2006). Coral reefs of Seribu Islands, Western Indonesia. Makalah pada 1st Asia Pacific Coral Reefs Symposium, Hongkong: $11 \mathrm{hlm}$.

Gomez, E., Alcala, A., Yap, H., Alcala, L., \& Alino, P. (1985). Growth studies of commercially important scleractinians. Proceedings of the 5th International Coral Reef Congress 6:199-204

González-Rivero, M., Yakob, L., \& Mumby, P. J. (2011). The role of sponge competition on coral reef alternative steady states. Ecol Model, 222(11), 1847-1853.

Gosliner, T., Behrens, D.W., \& Williams, G. C. (1996). Coral reefs animal of the Indo-Pacific. Sea Challengers, Monterey: vi $+314 \mathrm{hlm}$.

Hammerton, Z., \& Bucher, D. (2015). Levels of intervention - reducing SCUBA-diver impact within subtropical marine protected areas. Journal of Ecotourism, 14(1):3-20.

Harriott VJ, Davis D. Bank SA. (1997). Recreational Diving and Its Impact in Marine Protected Area in Eastern Australia.

Hawkins JP, CM Robert. (1992). Effect of Recreational Scuba Diving on Reef Slope Communities of Coral Reef. Biological Conservation.

Hill, J., \& Wilkinson, C. (2004). Methods for ecological monitoring of coral reefs: A resource for managers. Australian Institute of Marine Science and Reef Check, Australia.

Juhasz, A., Ho, E., Bender, E., \& Fong, P. (2010). Does use of tropical beaches by tourists and island residents result in damage to fringing coral reefs A case study in Moorea French Polynesia. Marine Pollution Bulletin, 60(12), 2251-2256. doi:http://dx.doi.org/10.1016/j. marpolbul.2010.08.011.

Kuiter, R. H., \& Tonozuka, T. (2003). Pictorial guide to: Indonesian reef fishes. Part 2. PT. Dive \& Dive's. Denpasar, Bali.

Laksono, A. N., \& Mussadun. (2014). Dampak Aktivitas Ekowisata di Pulau Karimunjawa Berdasarkan Persepsi Masyarakat. Jurnal Teknik PWK, 3(2), 262273.

Lieske, E. \& Myers, R. (1994). Reef fishes of the world. Reprinted 1997. Periplus Editions Ltd. Hongkong.

Liew, H. C. (2001). The Impact on Coral Reefs by Leisure Divers in Redang. National Symposium on Marine Park and Island in Trengganu.

Lim, L. C. (1998). The concepts and analysis of carrying capacity; A management tool for effective planning. Part I. Report produced under bay of Bengal Programme. Madras. India.

Ludwig, J. A., \& Reynolds, J. F. (1998). Statistical ecology: a primer methods and computing. John Wiley \& Sons, New York: xviii +337 hlm.
Madduppa. H. (2013). Bioekologi dan biosistematika Ikan Terumbu : Teknik Sampling Genetika dan Biomonitoring Studi Kasus Kepulauan Seribu, Petunjuk Identifikasi Ikan di Indonesia. IPB Press. Bogor.376 P.

Magurran, A. E. (1988). Ecological diversity and its measurements. Princeton University Press, Princeton: $\mathrm{x}+179 \mathrm{hlm}$.

Neter, J., Kutner, M. H., Nachtscheim, C. J., \& Wasserman, W. (1996). Applied Linear Statistical Models. Fourth Edition. Mc. Graw Hill: 1408 hlm.

Obura, D.O. \& Grimsdith, G. (2009). Resilience Assessment of coral reefs - Assessment protocol for coral reefs, focusing on coral bleaching and thermal stress. IUCN working group on Climate Change and Coral Reefs. IUCN, Gland, Switzerland. 70 pp.

Purwita, I. P. (2010). Pengelolaan wisata bahari dengan pendekatan ekosistem terumbu karang di Kelurahan Pulau Panggang, Kabupaten Administratif Kepulauan Seribu (dalam kegiatan diving dan snorkeling). Tesis. Fakultas Perikanan dan Ilmu Kelautan. Institut Pertanian Bogor.

Randall, J. E, Allen, G. R., \& Steene, R. C. (1997). Fish of The Great Barrier Reef and Coral Sea. Periplus Edition (HK) Ltd. Hongkong

Razak, T. (2006). Hard coral \& reef fish community on the EcoReefs rehabilitation site, Manado Tua Island, Bunaken National Park, North Sulawesi, Indonesia. A monitoring report, Indonesia: $35 \mathrm{hlm}$. (tidak dipublikasikan).

Sprung, J. (2001). Invertebrates: A Quick Reference Guide. Ricordea Publishing. Miami: 240 hlm.

Stoecker, D. (1978). Resistance of a tunicate to fouling. Bio. Bull. 155(3), 615-626.

Suwanborirux, K., Charupant, K., Amnuoypol, S., Pumangura, S., Kubo, A., \& Saito, N. (2002). Ecteinascidins 770 and 786 from the Thai tunicate Ecteinascidia thurstoni. J. Nat. Prod, 65(6), 935-937. Tomascik, T., Mah, A. J., Nontji, A., \& Moosa, M. K. (1997). The Ecology Of Indonesian Seas. Perplus Editions, $1387 \mathrm{p}$.

Veron, J. E. N. (2000). Corals of Australia and Indo-Pacific. Angus \& Robertson Publishers, Australia.

Wahab, M. A. A., Nys, R., Webster, N., \& Whalan, S. (2014). Larval Behaviours and their contribution to the distribution of the intertidal coral reef sponge Carteriospongia foliascens. PLOS ONE, 9(5), 1-13.

Yulianda, F. (2007). Ekowisata Bahari Sebagai Alternatif Pemanfaatan Sumberdaya Pesisir Berbasis Konservasi. [Makalah]. Seminar Sains Departemen Majemen Sumberdaya Perairan. FPIK. IPB. Bogor

Zhang, L. Y., Chung, S. S., \& Qiu, J. W. (2016). Ecological carrying capacity assessment of diving site: A case study of Mabul Island, Malaysia. Journal of Environmental Management, 183(1), 253-259.

Zul, D., Fibriarti, B. L., Yunita, M., Halimah, S., \& Komariah, S. (2013). Dampak Alih Fungsi Lahan Terhadap Biomassa Mikroba: Studi Kasus di Areal Bukit 
Batu, Riau. Prosiding Semirata. FMIPA Universitas

Lampung. Bandar Lampung. 
